\title{
Charakterystyka zdoIności siłowych w Rugby Union 15 na poziomie mistrzowskim
}

\section{Strength abilities characteristics of elite Rugby Union 15 players}

The purpose of this paper was to analyse the level of motor abilities in terms of strength abilities among the players of premier league for rugby union in Poland as well as defining the relationship between the level of the strength abilities and the sports level of the team.

Research material covered 79 players from three teams representing differential sports level which were selected from the Polish rugby premier league. The research included performing antropometric measurements, barbell squat maximal force and power output measurements, having been conducted with the use of Tendo Weightlifting Analyser.

It was indicated that the teams placed higher in the premier league were the ones with higher mean body mass of the players, which could have contributed to their scoring higher also in strength ability tests. Moreover, it was confirmed that the forwards have significantly higher body mass than the backs.

It appears that the most significant element in training rugby players is the possibility of obtaining high maximal power output of lower limbs, in its both, relative and non-relative aspect as well as force understood in the same context (relative and non-relative one).

\section{Wprowadzenie}

Wysoki poziom sportowy jest wynikiem wielu czynników, do których zaliczymy odpowiednie wyszkolenie techniczne, taktyczne, wysoki poziom rozwoju zdolności motorycznych, co jest rezultatem odpowiednio zaplanowanego procesu treningowego. Oczywiście nie sposób nie wskazać znaczenia wysokich wskaźników predyspozycji morfologicznych, funkcjonalnych, a także gotowości psychicznej (Bompa, Haff, 2010, Sozański, 2005, Sozański, i wsp. 2010). 
Osiągnięcie poziomu mistrzowskiego może być skutkiem różnych rozwiązań taktycznych, a także zróżnicowanego rozłożenia akcentów treningowych. Trenerzy mogą koncentrować się na wszechstronnym przygotowaniu motorycznym lub w jego obrębie preferują tylko wybrane akcenty motoryczne. Można też spotkać trenerów, którzy dopatrują się właściwych bodźców tylko i wyłącznie w grze - Game Related Conditioning (Gorostiaga i wsp., 1991), (Deutsch, 2006), traktując przygotowanie fizyczne jako element marginalny. Co ciekawe, wyniki mogą być zbliżone lub bardzo różne. W praktyce trenerskiej pojawiają się często dylematy o wyborze odpowiednich środków treningowych, których realizacja będzie zmierzać do odpowiednio „zbilansowanej” sprawności ogólnej lub też maksymalizacji najważniejszych zdolności (Wachowski, Strzelczyk, 1991).

Jedną z podstawowych zdolności motorycznych jest siła mięśniowa. Rozumiana jako zdolność pokonywania oporów lub przeciwstawiania się im na drodze wysiłku mięśniowego (Zaciorski, 1979), jest pojęciem bardzo ogólnym. Niemniej uznawana za zdolność pierwotną, warunkuje skuteczne przejawianie innych znamion motoryczności człowieka (Bompa, i in., 2013), a także jest konieczna dla ogólnego stanu zdrowia (Osiński, 2003), co w sporcie postrzegane jest również jako ważny czynnik zapobiegania urazom.

Ważnym elementem przygotowania sprawnościowego w sporcie jest przygotowanie siłowe. Jednak określając profil zawodnika, nie wystarczy wskazać na konieczność przejawiania odpowiedniego poziomu zdolności siłowych, bowiem zdolności te mogą mieć różny, czasem zupełnie odmienny charakter. Posługując się przykładem zawodnika trójboju siłowego, ciężarowca (dwuboisty) lub chociażby miotacza kulą stwierdzimy, że wszyscy trzej są silni. Jednak bez wątpienia przejaw zdolności siłowych w każdym przypadku znacznie się różni.

W opublikowanych dotychczas opracowaniach dotyczących wymagań stawianych przez grę podane zostały jedynie wybrane wskaźniki ilościowe, dotyczące wysiłków o charakterze siłowym, np. liczba określonych elementów oraz średni czas ich trwania (Deutsch, i wsp., 1998), (Roberts i wsp., 2008). Ze względów technicznych pomiar jakościowy poszukiwanych wskaźników w warunkach meczowych jest znacznie utrudniony, toteż uznać należy za zasadne podejmowanie poszukiwań w tym zakresie.

Należy zatem możliwie precyzyjnie określić jaki charakter owych zdolności winien być rozwijany, mając na uwadze osobnicze możliwości zawodnika, strukturę czasową treningu, a także funkcję zawodnika na boisku.

W literaturze autorzy przedstawiają różne przejawy zdolności siłowych. Siła absolutna określona jest jako maksymalna, możliwa do rozwinięcia przez zawodnika w typowych ćwiczeniach siłowych, np. przysiadzie, wyciskaniu, martwym ciągu itp. Jest to parametr dość istotny ze względu na możliwość określania obciążeń treningowych w odniesieniu do wartości procentowych maksymalnego obciążenia, z jakim zawodnik jest w stanie wykonać jedno powtórzenie maksymalne (1 RM- repetition maximum), np. 50-60\% 1RM, 70\% 1RM, 90-95\% 1RM, etc.

Pod pojęciem względnej siły mięśniowej, rozumiemy stosunek absolutnej siły mięśniowej do masy ciała zawodnika. W rywalizacji sportowej, celem obiektywizacji wyników, określono pewne formuły uwzględniające ww. iloraz, mianowicie 
w WSL i TS nieaktualne już formuły Shwartza i Malone’a (Schwartz, 2005) oraz obecnie obowiązującą Formułę Wilksa (Vandenbrugh, Batterham, 1999).

Pod dość szerokim pojęciem siły mięśniowej możemy zmieścić również możliwości siłowe przejawiane w jednostce czasu. Należy dodać, iż osiąganie dużej siły nie jest tożsame z możliwością szybkiego jej rozwijania. W warunkach pracy dynamicznej, związanej najczęściej z pokonywaniem małych oporów zewnętrznych, jednak na drodze maksymalnego przyspieszenia, zawodnik przejawia tzw. siłę eksplozywną lub RFD (race of force development). W tym miejscu należy zaznaczyć, że szybkość rozwijania siły i parametry ją określające nie są wskaźnikami mówiącymi bezpośrednio o mocy $(P)$ i dotyczą ruchów trwających do $250 \mathrm{~ms}$. Do owych parametrów zaliczamy np. gradient siły, charakteryzujący czas potrzebny do uzyskania $50 \%$ siły maksymalnej w danym ruchu, a także indeks prędkościowo-siłowy, określający stosunek maksymalnej wartości siły i czasu jej uzyskania. W warunkach pracy statycznej, gdzie długość mięśnia nie zmienia się, mamy do czynienia z siłą izometryczną. Natomiast w przypadku pracy auksotonicznej, gdzie momenty siły, rozwijane przez pracujące mięśnie są większe lub mniejsze od przyłożonych doń sił zewnętrznych, to charakter przejawianych momentów sił określić można odpowiednio siłą koncentryczną oraz ekscentryczną. Dzięki użyciu specjalnych trenażerów auto-oporujących (stały opór w całym zadaniu ruchowym), możliwe jest wygenerowanie siły izokinetycznej.

Niewątpliwie z punktu widzenia użytkowego siła mięśniowa (moment siły mięśniowej) i jej przejawy zaliczyć trzeba do podstawowych cech układu mięśniowego, jednak nie mniej istotną cechą jest moc, rozumiana jako zdolność do pokonania różnej wielkości oporu zewnętrznego, z możliwie największą prędkością ruchu. Istotna z punktu widzenia sportowego może być także lokalna wytrzymałość siłowa, stanowiąca zdolność wybranych mięśni lub grup mięśni do rozwijania określonej siły i utrzymania jej w określonym czasie (Trzaskoma, Trzaskoma, 2001).

W praktyce sportowej moc określana jest często jako siła dynamiczna i w odniesieniu do większości dyscyplin sportowych jest głównym przejawem możliwości siłowych. Zdolność zawodników do pokonywania oporów z jak największą prędkością wydaje się stanowić bardzo istotną cechę i na bazie ogólnego przygotowania siłowego to właśnie ten rodzaj możliwości siłowych jest promowany w końcowej fazie przygotowań. Z tego względu zdecydowano się na weryfikację znaczenia owego parametru.

Dodatkowo ze względu na acykliczność takich elementów jak szarże, młyny, maule i rucki (w odróżnieniu od np. biegów), koniecznym jest przejawianie najwyższej mocy przy obciążeniu zewnętrznym sięgającym 50-80\% ciężaru maksymalnego - 1RM (Bompa, i wsp., 2013).

$Z$ racji stosunkowo niewielkiej popularności dyscypliny w Polsce, nad poprawą czego usilnie pracują obecne władze PZRugby, a także władze poszczególnych klubów, nabór do dyscypliny ma wciąż charakter głównie "negatywny”. Zgłaszający się chętni nie są nawet poddawani dalszej selekcji (Powała-Niedźwiecki, 2005). W związku z tym, iż „model mistrza” w rugby nie jest jeszcze w pełni ustalony, proces szkoleniowy może być nieadekwatny w stosunku do potrzeb 
wynikających z gry, o ile w ogóle można mówić o procesie w przypadku wielu klubów. Problem po części wynika także i z niewielkiej liczby opracowań zarówno naukowych, jak i metodyczno-szkoleniowych.

Zawodnicy poszczególnych formacji mogą charakteryzować się różną budową somatyczną i przygotowaniem motorycznym, co zapewne wynika z różnych funkcji realizowanych przez wspomniane formacje na boisku (Powała-Niedźwiecki, 2005).

Wymagania, jakie stawia dyscyplina, dotyczą wielu elementów technicznych i taktycznych. Elementy stosowane w grze zawierają bardzo szeroki wachlarz czynności. Są to między innymi biegi o różnej intensywności, rzuty, skoki, mocowania, kopnięcia, pady, etc. Przepisy zezwalają na grę rękoma i nogami, przez co wymaga to od zawodnika wysokiej sprawności motorycznej, zwłaszcza o charakterze siłowym.

Celem badań było dokonanie charakterystyki somatycznej oraz analiza poziomu sprawności motorycznej, w aspekcie szeroko pojmowanej siły mięśniowej, zawodników polskiej ekstraligi rugby, na podstawie drużyn reprezentujących różny poziom sportowy. Za wskaźnik poziomu sportowego przyjęto miejsce w tabeli rozgrywek ligowych. Współwystępowanie poszukiwanych wskaźników określono na podstawie rankingu trenerskiego - metody „pierwszego wyboru”, która uwzględnia przydatność zawodnika do gry, zarówno na swojej pozycji jak i w grze otwartej (Wachowski, Strzelczyk, 1991, Bennett i wsp. 2010).

Analizę przeprowadzono, uwzględniając przynależność zawodników do określonej formacji, mianowicie młyn i atak, ze względu na różnice wynikające z funkcji pełnionych na boisku.

\section{Metodologia badań}

Badaniami objęto zawodników trzech drużyn polskiej ekstraligi rugby, $\mathrm{n}=79$. Byli to zawodnicy drużyn „Lechii” Gdańsk (lider tabeli), „Ogniwa” Sopot (środek tabeli) i „Posnanii” Poznań (koniec tabeli). O wyborze drużyn stanowiło aktualne miejsce w tabeli oraz osiągnięcia z sezonu 2012/2013 oraz 2013/2014.

Najniższą średnią wieku charakteryzował się zespół z Poznania 23,65 lat, przy zróżnicowaniu 18-41 lat. Pozostałe drużyny okazały się „starsze”, a wartości średnie wynosiły 26,63 lat dla zespołu z Sopotu i 27,11 lat dla zespołu z Gdańska, przy zróżnicowaniu odpowiednio 22-36 lat oraz 19-37 lat. Średni staż gry odnośnie do wszystkich drużyn wynosił 10,87 lat. Wysokość ciała zawodników była zbliżona we wszystkich zespołach, a średnia jej wartość wyniosła $181,21 \mathrm{~cm}$, przy rozpiętości od 170 do $190 \mathrm{~cm}$. Masa ciała poszczególnych zawodników w drużynach przybierała dość zróżnicowane wartości, od 66 do 121 kg, przy czym wartości średnie masy ciała dla drużyn także przyjmowały znacząco różne wartości: dla „Posnanii” Poznań 92,1 kg, dla „Ogniwa” Sopot 96,9 kg, a dla „Lechii” Gdańsk 99,06 kg. Szczegółowa analiza parametrów somatycznych przedstawiona zostanie w kolejnym punkcie. 
Badania przeprowadzono $\mathrm{w}$ dniach 3-24.03.2014, tj. w okresie przygotowawczym, drugiej rundy sezonu 2013/2014.

Pomiarów dokonywano w sali gimnastycznej oraz siłowni. Wszystkie drużyny wykonywały próby w takich samych warunkach i o podobnej porze. Próby były wykonywane zawsze w tej samej kolejności, zgodnie z wymaganą metodyką, poprzedzone 10-min rozgrzewką.

Pomiar obejmował zdolności siłowe w ćwiczeniu, jakim jest wstawanie ze sztangą z półprzysiadu. Określono poziom siły maksymalnej (Fmax), mocy maksymalnej (Pmax), siły względnej ( $\mathrm{Fmax} / \mathrm{mc})$, mocy względnej $(\mathrm{Pmax} / \mathrm{mc})$; obciążenie, przy którym zawodnicy uzyskiwali najwyższą moc rozpatrywano zarówno w ujęciu bezwzględnym (Ciężar ${ }_{\text {Pmax }}$ ), jak i względnym (Ciężar $\left.{ }_{\text {Pmax }} / \mathrm{mc}\right)$.

Pomiaru mocy dokonano w siłowni lub hali sportowej, przy użyciu analizatora Tendo Weightlifting Analyser. Urządzenie pozwala na bezpośrednie odczytanie wartości generowanej mocy $(P)$ poprzez pomiar przyspieszenia i prędkości uzyskiwanej w danym ruchu, pomnożonej przez obciążenie zewnętrzne.

Celem pierwszego badania było określenie mocy maksymalnej oraz obciążenia, przy którym zawodnik uzyskał najwyższą moc ( $\mathrm{P}$ max). Dokonano tego w kilku seriach wstawania z półprzysiadu, ze sztangą trzymaną na barkach. Linka pomiarowa urządzenia TENDO przyłączona była do skrajnego brzegu sztangi, celem wyeliminowania kontaktu ćwiczącego $z$ linką pomiarową. Kąt w stawach kolanowych nie mógł być większy niż $90^{\circ}$.

Zadaniem było wykonanie kilku serii, składających się z jednego powtórzenia. Po każdej serii zwiększano obciążenie o $10 \mathrm{~kg}$. W momencie gdy różnica między dwoma ostatnimi pomiarami wynosiła mniej niż 100 [W], zwiększano obciążenie o $5 \mathrm{~kg}$. Pomiar prowadzono do momentu spadku wartości $P$ max, wyświetlanej na wyświetlaczu urządzenia w kolejnych dwóch próbach, lub nieprawidłowej techniki wykonania ćwiczenia (za duży kąt w stawach kolanowych). Przyjmowano wartość najwyższą (Poprawski, Winkler 1976).

Warunki pomiaru siły były takie same jak podczas pomiaru mocy maksymalnej. Zastosowano metodę bezpośrednią, dochodząc do obciążenia, z którym ćwiczący był wstanie wykonać tylko jedno powtórzenie.

Dane analizowano $z$ wykorzystaniem podstawowych metod statystycznych. Wyznaczono wartości średnie, maksymalne i minimalne oraz odchylenie standardowe.

\section{Wyniki}

W związku z aktualnym, na czas badań, miejscem w tabeli, a także aktualne mistrzostwo Polski (sezon 2012/2013, 2013/2014), zespół „Lechii” Gdańsk uznano za najlepszą drużynę ekstraligi. Środkową pozycję w tabeli reprezentuje zespół „Ogniwa” Sopot, który po chwilowym niebycie powrócił do rozgrywek ekstraligowych. Drużyna „Posnanii” Poznań znajduje się w końcowej części tabeli. Jak wynika $z$ danych, jest drużyną najmłodszą, a jej zawodnicy mają najkrótszy staż treningowy. 
Tabela 1. Charakterystyka wysokości i masy ciała zawodników w opisywanych zespołach rugby

\begin{tabular}{|l|c|c|c|c|c|c|c|c|}
\hline \multirow{2}{*}{ Drużyna } & \multicolumn{4}{|c|}{ Wysokość ciała [cm] } & \multicolumn{4}{c|}{ Masa ciała [kg] } \\
\cline { 2 - 9 } & $\overline{\boldsymbol{X}}$ & $\boldsymbol{\Sigma}$ & $\min$ & $\max$ & $\overline{\boldsymbol{X}}$ & $\boldsymbol{\sigma}$ & $\min$ & $\max$ \\
\hline $\begin{array}{l}\text { "Lechia" } \\
\text { Gdańsk }\end{array}$ & $\mathbf{1 8 0 , 7 1}$ & 5,11 & 173 & 190 & $\mathbf{9 9 , 0 6}$ & 11,38 & 85 & 121 \\
\hline $\begin{array}{l}\text { "Ogniwo" } \\
\text { Sopot }\end{array}$ & $\mathbf{1 8 1 , 6 8}$ & 5,65 & 170 & 190 & $\mathbf{9 6 , 9 0}$ & 11,9 & 73 & 115 \\
\hline $\begin{array}{l}\text { Posnania" } \\
\text { Poznań }\end{array}$ & $\mathbf{1 8 1 , 8 4}$ & 4,85 & 174 & 189 & $\mathbf{9 1 , 9 5}$ & 12,18 & 66 & 115 \\
\hline Kadra & $\mathbf{1 8 1 , 4}$ & 3,79 & 173 & 188 & $\mathbf{9 5}$ & 9,21 & 73 & 121 \\
\hline
\end{tabular}

Źródło: badania własne.

Przedstawione w tabeli 1 dane wskazują, że badane zespoły nie różnią się znacząco pod względem wysokości ciała zawodników przy dość wyraźnym zróżnicowaniu wewnętrznym, czego obrazem jest znaczna rozpiętość wyników minimalnych i maksymalnych. Celem porównania, przedstawiono również wartości wysokości i masy ciała zawodników wybranych spośród badanych, stanowiących część kadry Polski. Średnie wartości tej cechy układają się na poziomie około $181 \mathrm{~cm}$. Zatem można przyjąć, że ta cecha nie jest parametrem decydującym o poziomie sportowym badanych.

Bardziej zaznaczone różnice stwierdzono w przypadku wyników pomiarów masy ciała. Najlepszy zespół w lidze charakteryzował się najwyższą masą ciała $(99,06 \mathrm{~kg})$. Zawodnicy „Ogniwa” Sopot charakteryzowali się masą ciała niższą o około $2 \mathrm{~kg}$, natomiast „Posnanii” o blisko $7 \mathrm{~kg}$. Może to sugerować, iż ten parametr (związany z masą mięśniową) może mieć wpływ na poziom siły i mocy mięśniowej zawodników i zespołów, a w konsekwencji na poziom sportowy. Wybrani zawodnicy będący „kadrowiczami”, stanowią grupę charakteryzującą się masą ciała zbliżoną do średnich wartości poszczególnych drużyn.

W celu dokładnego zbadania zależności między poziomem sportowym a miejscem drużyny w tabeli dokonano podziału zawodników na dwie podstawowe formacje: młyna i ataku. Dane dotyczące parametrów somatycznych przedstawiono $w$ tabeli 2 i 3.

Stwierdzono, że zawodnicy formacji młyna we wszystkich zespołach ponownie charakteryzują się zbliżoną wysokością ciała, a różnice dotyczą głównie masy ciała. Ten parametr pośrednio wpływa na wygrywanie stałych fragmentów gry, przewidzianych dla tej formacji. Różnica średniej masy ciała w młynach „Lechii” i „Posnanii” wynosi blisko $8 \mathrm{~kg}$. Także skrajne wartości w przypadku „Lechii” są najwyższe (94 kg i $121 \mathrm{~kg}$ ). Średnia masa ciała w formacji obronnej „Ogniwa” jest o 5 kg wyższa od średniej wartości „Posnanii”.

Porównanie formacji ataku poszczególnych drużyn pozwala stwierdzić, że i w tym wypadku zawodnicy "Lechii” okazują się być ciężsi niż zawodnicy „Ogniwa” i „Posnanii”. Średnia wartość masy ciała ataku „lechitów” przewyższa „ogniwian" i zawodników z Poznania o blisko $5 \mathrm{~kg}$. 
Tabela 2. Charakterystyka wysokości i masy ciała zawodników formacji młyna

\begin{tabular}{|l|c|c|c|c|c|c|c|c|}
\hline \multirow{2}{*}{ Drużyna } & \multicolumn{4}{|c|}{ Wysokość ciała [cm] } & \multicolumn{4}{c|}{ Masa ciała [kg] } \\
\cline { 2 - 9 } & $\overline{\boldsymbol{X}}$ & $\boldsymbol{\sigma}$ & $\min$ & $\operatorname{Max}$ & $\overline{\boldsymbol{X}}$ & $\boldsymbol{\sigma}$ & $\min$ & $\max$ \\
\hline $\begin{array}{l}\text { "Lechia" } \\
\text { Gdańsk }\end{array}$ & $\mathbf{1 8 1 , 6}$ & 5,85 & 173 & 190 & $\mathbf{1 0 5 , 7}$ & 9,64 & 94 & 121 \\
\hline $\begin{array}{l}\text { "Ogniwo" } \\
\text { Sopot }\end{array}$ & $\mathbf{1 8 1 , 5}$ & 6,01 & 170 & 190 & $\mathbf{1 0 3 , 0}$ & 9,09 & 87 & 115 \\
\hline $\begin{array}{l}\text { "Posnania" } \\
\text { Poznań }\end{array}$ & $\mathbf{1 8 1 , 8}$ & 5,46 & 174 & 189 & $\mathbf{9 8 , 0}$ & 10,0 & 85 & 115 \\
\hline
\end{tabular}

Źródło: badania własne.

Tabela 3. Charakterystyka wysokości i masy ciała zawodników formacji ataku

\begin{tabular}{|l|c|c|c|c|c|c|c|c|}
\hline \multirow{2}{*}{ Drużyna } & \multicolumn{4}{|c|}{ Wysokość ciała [cm] } & \multicolumn{4}{c|}{ Masa ciała [kg] } \\
\cline { 2 - 9 } & $\overline{\boldsymbol{X}}$ & $\boldsymbol{\sigma}$ & $\min$ & $\operatorname{Max}$ & $\overline{\boldsymbol{X}}$ & $\boldsymbol{\sigma}$ & $\min$ & $\max$ \\
\hline $\begin{array}{l}\text { "Lechia" } \\
\text { Gdańsk }\end{array}$ & $\mathbf{1 8 1 , 1}$ & 5,46 & 173 & 190 & $\mathbf{9 1 , 3}$ & 7,04 & 85 & 102 \\
\hline $\begin{array}{l}\text { "Ogniwo" } \\
\text { Sopot }\end{array}$ & $\mathbf{1 8 2 , 0}$ & 5,37 & 175 & 188 & $\mathbf{8 6 , 7}$ & 8,73 & 73 & 100 \\
\hline $\begin{array}{l}\text { "Posnania" } \\
\text { Poznań }\end{array}$ & $\mathbf{1 8 1 , 6}$ & 4,88 & 174 & 188 & $\mathbf{8 6 , 3}$ & 10,44 & 66 & 100 \\
\hline
\end{tabular}

Źródło: badania własne.

Obserwując różnice w budowie ciała pomiędzy formacją młyna i ataku, należy stwierdzić, że przy zbliżonej wysokości ciała zawodnicy młyna charakteryzują się znacznie wyższą masą ciała niż atakujący. Najniższą różnicę między formacjami stwierdzono w zespole „Posnanii”, która wynosiła około $12 \mathrm{~kg}$, natomiast najwyższą w zespole „Lechii” i było to około $16 \mathrm{~kg}$.

W tabeli 4 zestawiono dane charakteryzujące badane zespoły pod względem przygotowania siłowego. Wykorzystując Tendo Weightlifting Analyser, wyznaczono moc maksymalną oraz określono ciężar, przy którym poszukiwany parametr był uzyskiwany.

Zebrane dane wskazują, iż najwyższą moc maksymalną rozwijają zawodnicy zespołu o najwyższym poziomie sportowym. W zespołach o niższym poziomie sportowym obserwowano niższe wyniki w tej próbie. Ponadto warte uwagi jest obciążenie, przy którym badani rozwijali najwyższą moc; w opracowaniu oznaczone jako Ciężar ${ }_{\text {max }}[\mathrm{kg}]$. Zawodnicy „Lechii” rozwijali najwyższą moc maksymalną przy najwyższym obciążeniu, średnio $122 \mathrm{~kg}$, rugbiści z Sopotu $112,14 \mathrm{~kg}$, zawodnicy z Poznania 104,4 kg. Wydaje się, iż duże znaczenie ma komponent siłowy, na bazie którego generowana jest wysoka moc maksymalna. Potwierdzają to dane dotyczące poddanych badaniom zawodników kadry Polski. Średnia wartość mocy maksymalnej Pmax przewyższa ten sam wskaźnik w najlepszym zespole w lidze. Dodatkowo na uwagę zasługuje najmniejsza wartość odchylenia standardowego. 
Tabela 4. Charakterystyka liczbowa wskaźników siłowych analizowanych drużyn

\begin{tabular}{|l|c|c|c|c|}
\hline \multicolumn{1}{|c|}{ Test } & "Lechia" Gdańsk & "Ogniwo" Sopot & $\begin{array}{c}\text { "Posnania” } \\
\text { Poznań }\end{array}$ & Kadra \\
\hline$\overline{\mathbf{X}} \overline{\mathbf{X}}$ Pmax [W] & $\mathbf{1 5 7 8}$ & $\mathbf{1 4 6 6}$ & $\mathbf{1 3 1 6}$ & $\mathbf{1 5 9 3}$ \\
\hline$\Sigma$ & 247,45 & 262,18 & 326,95 & 214,33 \\
\hline Min & 1147 & 1085 & 772 & 1041 \\
\hline Max & 2023 & 1948 & 2177 & 2177 \\
\hline$\overline{\mathbf{X}} \overline{\mathbf{X}}$ Pmax ciężar $[\mathrm{kg}]$ & $\mathbf{1 2 2}$ & $\mathbf{1 1 2 , 1 4}$ & $\mathbf{1 0 4 , 4 0}$ & $\mathbf{1 2 0 , 8 8}$ \\
\hline$\Sigma$ & 11,52 & 17,06 & 19,40 & 12,11 \\
\hline Min & 100 & 85 & 70 & 90 \\
\hline Max & 140 & 140 & 150 & 150 \\
\hline $\begin{array}{l}\text { Quasi INDEKS P-S } \\
\text { CPmax/Pmax/CPmax }\end{array}$ & $\mathbf{9 , 4 3 5}$ & $\mathbf{8 , 5 3 2}$ & $\mathbf{8 , 2 7 9}$ & $\mathbf{9 , 1 7 8}$ \\
\hline$\overline{\mathbf{X}} \overline{\mathbf{X}}$ Pmax[W]/ & $\mathbf{1 2 , 9 3}$ & $\mathbf{1 3 , 0 7}$ & $\mathbf{1 2 , 6 0}$ & $\mathbf{1 3 , 1 8}$ \\
$\overline{\mathbf{X}} \mathbf{X}$ Ciężar $_{\text {Pmax }}[\mathrm{kg}]$ & & & & \\
\hline
\end{tabular}

Źródło: badania własne.

Wyniki uzyskane w pomiarze mocy maksymalnej odniesiono do masy ciała zawodników, uzyskując dodatkowy wskaźnik, tj. maksymalną moc względną. Dzięki temu przelicznikowi uzyskujemy informację dotyczącą „wytrenowania kilogramów masy ciała zawodnika". Maksymalna moc względna wydaje się być ważnym wskaźnikiem wytrenowania, bowiem jej średnia wartość jest zbieżna z poziomem sportowym drużyny. Co warte podkreślenia, to wskaźnik ten dla grupy zawodników o najwyższym poziomie sportowym (kadra) przybiera najwyższą wartość tj. 16,84 [W/kg], co jest wartością o 1 [W/kg] wyższą niż w przypadku najlepszego zespołu w lidze. Zwraca to uwagę na możliwe duże znaczenie przejawiania wysokiej mocy względnej. Warto zwrócić uwagę na kształtowanie się tego wskaźnika w odrębnych formacjach.

Dane przedstawione na rycinie 1 wskazują, że najwyższe wartości tego wskaźnika uzyskali kadrowicze, czyli zawodnicy wyselekcjonowani. Spośród opisywanych drużyn, „Lechia” Gdańsk, czyli lider tabeli ligowej, uzyskał najwyższą wartość opisywanego wskaźnika $(15,84 \mathrm{~W} / \mathrm{kg})$. Niższe wartości uzyskali rugbiści „Ogniwa” oraz „Posnanii”. Moc względna może być znacząca przy określaniu poziomu sportowego drużyny, o czym stanowi zbieżność wartości omawianego wskaźnika z miejscem zajmowanym w tabeli ligowej. 


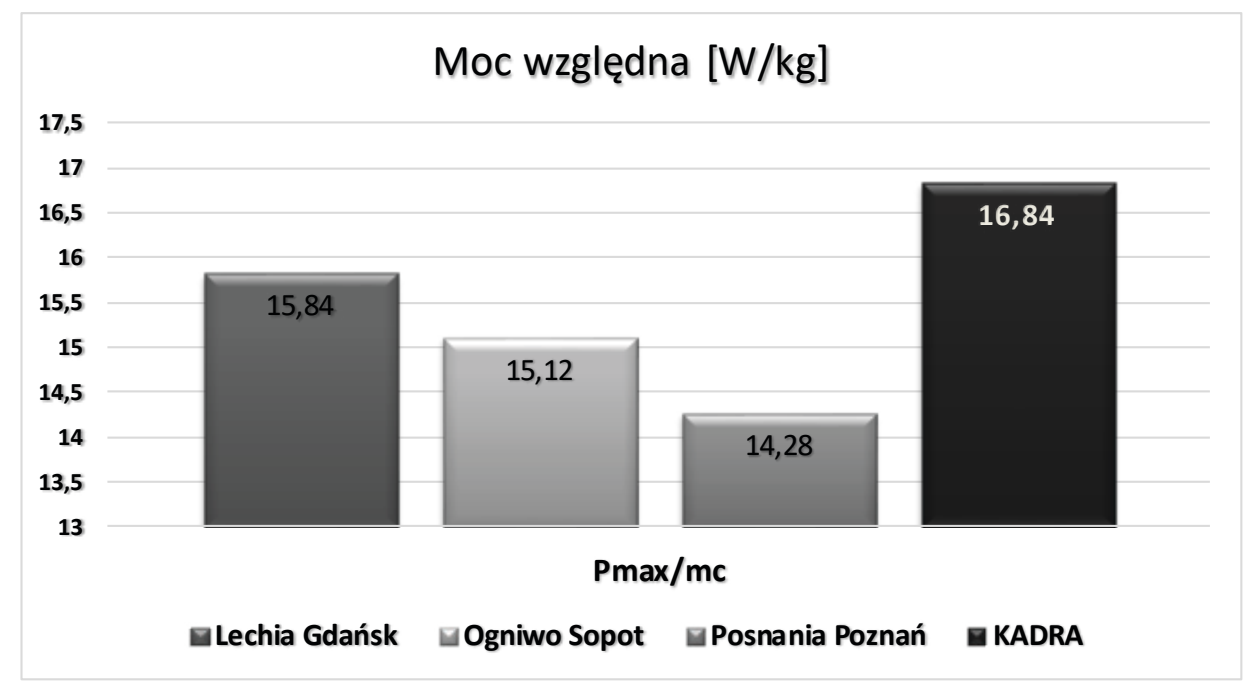

Rycina 1. Charakterystyka graficzna stosunku uśrednionych wartości mocy maksymalnej do średniej drużynowej masy ciała. Porównanie średnich wartości mocy względnej w poszczególnych zespołach

Źródło: badania własne.

Tabela 5. Charakterystyka stosunku uśrednionych wartości mocy maksymalnej do średniej drużynowej masy ciała, w poszczególnych formacjach

\begin{tabular}{|l|c|c|c|}
\hline \multicolumn{1}{|c|}{ Formacja } & „Lechia” Gdańsk & „Ogniwo” Sopot & „Posnania” Poznań \\
\hline Młyn [W/kg] & 15,58 & 15,11 & 13,93 \\
\hline Atak $[\mathrm{W} / \mathrm{kg}]$ & 16,37 & 15,01 & 14,33 \\
\hline
\end{tabular}

Źródło: badania własne.

Wartość maksymalnej mocy względnej (drużynowej), z uwzględnieniem odrębności formacji młyna i ataku, również wskazuje na dominację „Lechii”, jak też na możliwe znaczenie tego wskaźnika w określaniu poziomu sportowego. Warte uwagi jest przejawianie wyższej mocy względnej w formacjach ataku w porównaniu z formacją młyna „Lechii” i „Posnanii”.

Jak już wspomniano, istotnym wskaźnikiem może być także obciążenie, przy którym generowana jest moc maksymalna. Wyniki tej próby można przyjąć za odzwierciedlenie zdolności siłowych, mając na uwadze zależność pomiędzy aplikowanym obciążeniem a mocą maksymalną.

W opracowaniu, jak wspomniano, podjęto próbę określenia zależności pomiędzy wynikami uzyskanymi w próbach siłowych a poziomem sportowym zawodników. Poszukując związku, postanowiono uzyskane wyniki odnieść do rankingu trenerskiego, tzw. „pierwszego wyboru” (Bennett i wsp. 2010).

Współwystępowanie poszczególnych wskaźników z miejscem zajmowanym w drużynie w formacjach młyna przedstawiono w tabeli 7 . 
Stwierdzono występowanie korelacji, a współczynniki istotne statystycznie odnotowano drukiem pogrubionym.

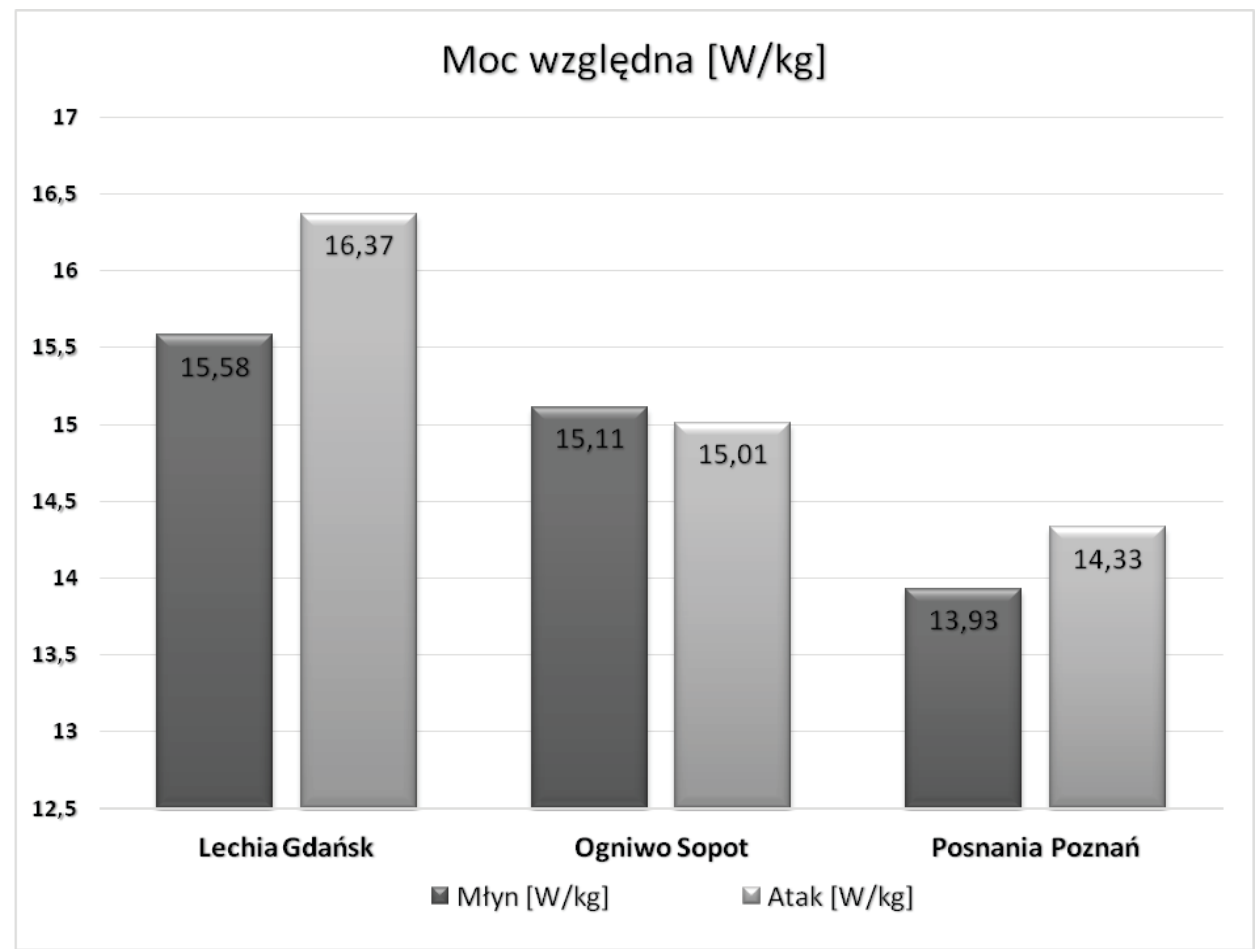

Rycina 2. Charakterystyka graficzna uśrednionych wartości mocy maksymalnej względnej, w poszczególnych formacjach

Źródło: badania własne.

Tabela 6. Charakterystyka wskaźników obciążenia zewnętrznego, przy którym uzyskiwana była moc maksymalna, w stosunku do masy ciała

\begin{tabular}{|l|c|c|c|}
\hline \multicolumn{1}{|c|}{ Nazwa klubu } & $\mathbf{X}^{-}$Ciężar $_{\text {Pmax }}[\mathbf{k g}]$ & $\mathbf{X}^{-}$masy ciała $[\mathbf{k g}]$ & $\mathbf{X}^{-}$Ciężar $_{\text {Pmax }} / \mathbf{X}^{-} \mathbf{m c}[\mathbf{k g}]$ \\
\hline "Lechia” Gdańsk & 122 & 99,6 & $\mathbf{1 2 2 , 5 \%} \mathbf{m c}$ \\
\hline „Ogniwo" Sopot & 112,14 & 96,9 & $\mathbf{1 1 5 , 7 \% m c}$ \\
\hline „Posnania” Poznań & 104,4 & 92,1 & $\mathbf{1 1 3 , 3} \% \mathbf{m c}$ \\
\hline Kadra & 120,88 & 95,4 & $\mathbf{1 2 6 , 7 \% m c}$ \\
\hline
\end{tabular}

Źródło: badania własne. 
Tabela 7. Występowanie związku pomiędzy wybranym przejawem zdolności siłowych a poziomem sportowym zawodników w formacji młyna $(p=0,05)$

\begin{tabular}{|l|c|c|c|}
\hline \multicolumn{1}{|c|}{ Formacja młyna } & \multicolumn{3}{|c|}{ Zespoły } \\
\hline \multicolumn{1}{|c|}{ Zdolności siłowe } & „Lechia” Gdańsk & „Ogniwo” Sopot & „Posnania” Poznań \\
\hline Pmax [W] & 0,272 & $\mathbf{0 , 7 0 0}$ & 0,362 \\
\hline $\begin{array}{l}\text { Pmax/masa ciała } \\
{[\mathrm{W} / \mathrm{kg}]}\end{array}$ & 0,166 & 0,600 & 0,462 \\
\hline Pmax [kg] & $\mathbf{0 , 5 3 1}$ & 0,520 & 0,533 \\
\hline
\end{tabular}

Źródło: badania własne.

Podobnie postąpiono z wynikami uzyskanymi przez zawodników formacji ataku. Wyniki przedstawia tabela 8.

Tabela 8. Występowanie związku pomiędzy wybranym przejawem zdolności siłowych a poziomem sportowym zawodników $w$ formacji ataku $(p=0,05)$

\begin{tabular}{|l|c|c|c|}
\hline \multicolumn{1}{|c|}{ Formacja ataku } & \multicolumn{3}{|c|}{ Zespoły } \\
\hline \multicolumn{1}{|c|}{ Zdolności siłowe } & „Lechia” Gdańsk & „Ogniwo” Sopot & „Posnania” Poznań \\
\hline Pmax [W] & $-0,046$ & $\mathbf{0 , 9 0 0}$ & 0,430 \\
\hline $\begin{array}{l}\text { Pmax/masa ciała } \\
{[\mathrm{W} / \mathrm{kg}]}\end{array}$ & 0,107 & $\mathbf{0 , 7 0 0}$ & $\mathbf{0 , 7 0 0}$ \\
\hline Ciężar $_{\text {Pmax }}[\mathrm{kg}]$ & 0,017 & 0,600 & 0,383 \\
\hline
\end{tabular}

Źródło: badania własne.

Wskaźnik Ciężar ${ }_{\text {Pmax }}[\mathrm{kg}]$ dotyczący obciążenia, przy którym zawodnicy uzyskiwali moc maksymalną, przyjęty został jako szacunkowy wskaźnik siłowy. Dodatkowo w drużynie „Posnanii” Poznań określono bezpośrednio wskaźniki dotyczące siły maksymalnej, uzyskiwanej w jednym powtórzeniu maksymalnym - 1RM, w ujęciu bezwzględnym i względnym.

Tabela 9. Występowanie związku pomiędzy wybranym przejawem siły mięśniowej, a poziomem sportowym zawodników „Posnanii” Poznań $(p=0,05)$

\begin{tabular}{|l|c|c|}
\hline \multirow{2}{*}{ Zdolności siłowe } & \multicolumn{2}{|c|}{ „Posnania” Poznań } \\
\cline { 2 - 3 } & formacja młyna & formacja ataku \\
\hline Pmax $[\mathrm{W}]$ & 0,362 & 0,430 \\
\hline Pmax/masa ciała $[\mathrm{W} / \mathrm{kg}]$ & 0,462 & $\mathbf{0 , 7 0 0}$ \\
\hline Ciężar $_{\text {Pmax }}[\mathrm{kg}]$ & 0,533 & 0,383 \\
\hline $\mathrm{F}(1 \mathrm{RM})[\mathrm{kg}]$ & $\mathbf{0 , 8 0 6}$ & 0,416 \\
\hline $\mathrm{F}(1 \mathrm{RM}) / \mathrm{masa}$ ciała $[\mathrm{kg}]$ & $\mathbf{0 , 9 8 8}$ & $\mathbf{0 , 7 3 0}$ \\
\hline
\end{tabular}

Źródło: badania własne. 


\section{Dyskusja}

Bez wątpienia poziom sprawności fizycznej ma wpływ na charakter rywalizacji, rozwiązania taktyczne, a ostatecznie na wynik sportowy. W tak wymagającej dyscyplinie jaką jest rugby siła mięśniowa wydaje się być jednym z najbardziej istotnych elementów przygotowania. Należy zauważyć, iż ogólne pojęcie siły nie wyczerpuje względnie precyzyjnych oczekiwań stawianych zawodnikom w poszczególnych formacjach. Wysoce pożądanym wydaje się możliwie precyzyjne określenie wymagań dotyczących przygotowania siłowego.

W trakcie badań stwierdzono znaczne zróżnicowanie poziomu zdolności o charakterze siłowym wśród badanych zawodników/zespołów. Świadczyć to może o pewnych niedostatkach wynikających z procesu szkolenia. Szczególnie w formacji młyna, mając na uwadze stabilność tej formacji w stałych fragmentach gry, jak również działania defensywne, wydaje się zasadne takie postępowanie treningowe, ażeby w kolejnych terminach badań zawodnicy nie tylko uzyskiwali wysokie wskaźniki bezwzględne i względne, ale również wartości min/max wskazywały na jak najmniejsze odchylenie od średniej wartości drużyny, przy jak najmniejszym SD.

Badając związek pomiędzy uzyskiwanymi wskaźnikami a poziomem sportowym zawodników, który określono na podstawie rankingu trenerskiego, stwierdzono, iż w zespole „Lechii” Gdańsk dominowały możliwości do przejawiania mocy maksymalnej względnej w formacji młyna.

W zespole „Ogniwa” Sopot na uwagę zasługuje zdolność do wygenerowania wysokiej mocy maksymalnej zarówno bezwzględnej, jak i względnej, w obu formacjach.

W zespole „Posnanii” Poznań znaczącą rolę odgrywa zdolność wygenerowania maksymalnej mocy i maksymalnej siły w ujęciu względnym, zwłaszcza w formacji ataku, a także maksymalnej siły bezwzględnej i względnej w formacji młyna.

Należy mieć na uwadze fakt, że ranking trenerski lub miejsce zajmowane w tabeli, nie uwzględnia wielu innych uwarunkowań mistrzostwa sportowego. Niemniej jednak wskazuje na występowanie pewnych wskaźników o określonych wartościach wśród zawodników postrzeganych za najbardziej przydatnych w grze.

Odrębność formacji wynika z funkcji pełnionych na boisku, a także wymagań stawianych przez grę. Znajduje to swoje odzwierciedlenie w wynikach prowadzonych badań. Poza różnicami w budowie somatycznej, obserwuje się również odmienny charakter przejawiania możliwości o charakterze siłowym.

Za element niezwykle istotny przyjęto tutaj najwyższą możliwą wartość mocy (Pmax), która - jak wspomniano - często akcentowana bywa w procesie przygotowania motorycznego w różnych dyscyplinach. Wydaje się, że w rugby możliwości siłowe zawodników powinny być kształtowane w odpowiedni sposób.

Możliwości siłowe winny być rozpatrywanie zwłaszcza w funkcji czasu, czyli prędkości (czasu trwania) ruchu, a także intensywności - obciążenia. Zawsze mamy do czynienia z dynamicznym charakterem wykonywanych czynności, niemniej różny bywa charakter oraz czas ich trwania. Od kilku sekund w młynach, 
ruckach, maulach i charakterze acyklicznym, do skrajnie nawet kilkunastu w przypadku sprintów i ruchów cyklicznych. W związku z czym także i wartość obciążenia w treningu siłowym ukierunkowanym na poprawę wskaźników mocy winna być odrębnie dobierana, np. 30-50\% 1RM dla ruchów cyklicznych oraz 50-80\%1RM dla ruchów acyklicznych (Bompa i wsp., 2013).

Nie bez znaczenia okazuje się tu wiek zawodników oraz staż, co może określać nie tylko doświadczenie, ale również, a może przede wszystkim wynikiem tego może być pewna stabilizacja formy, która wymagana jest na poziomie mistrzowskim. Pozwala to określić pewien kierunek działania trenerów, zwłaszcza w odniesieniu do zawodników młodszych, wchodzących dopiero w wiek seniora, którzy nie padli ofiarą zbyt wczesnej specjalizacji i pod warunkiem właściwie planowanego treningu, mają szansę rywalizować w przyszłości o najwyższe trofea.

Reasumując, w formacjach młyna o poziomie sportowym decyduje przede wszystkim moc maksymalna, siła względna i bezwzględna oraz moc względna.

W formacjach ataku istotna jest moc maksymalna, a także siła i moc względna.

Można przyjąć, że miejsce drużyny w lidze, jest dodatnie skorelowane z poziomem mocy maksymalnej w ujęciu bezwzględnym i względnym, siły.

\section{Wnioski}

1. Stwierdzono, że drużyny zajmujące wyższe miejsce w lidze charakteryzowały się wyższą wartością średnią masy ciała zawodników, zarówno w formacji młyna, jak i w formacji ataku.

2. Wyższa masa ciała wynikać może z wyższej masy mięśniowej, co sprzyja uzyskiwaniu wyższych wartości w testach sprawności o charakterze siłowym. Jednocześnie zawodnicy młyna charakteryzowali się wyraźnie wyższą masą ciała niż zawodnicy formacji ataku.

3. Wyniki badań sugerują, iż większe znaczenie może mieć zdolność do wygenerowania wysokiej mocy wynikającej ze znacznego obciążenia zewnętrznego, przy nadal zachowanej wysokiej prędkości ruchu w formacji młyna; w formacji ataku, przede wszystkim moc maksymalna w ujęciu względnym.

\section{Literatura}

Bennett M., Manning T.J., Cook C.J., Kilduff L.P., 2010, Digit ratio (2D:4D) and performance in elite rugby players, „Journal of Sports Sciences”, vol. 28(13), s. 1415-1421.

Bober T., Zawadzki J., 2003, Biomechanika układu ruchu człowieka, Wydawnictwo BK, Warszawa.

Bompa T.O., 1999, Periodization. Theory and Methodology of Training, Human Kinetics.

Bompa T.O., Haff G.G., 2010, Periodyzacja: teoria i metodyka treningu, Centralny Ośrodek Sportu, Warszawa.

Bompa T.O., Zając A., Waśkiewicz Z., Chmura J., 2013, Przygotowanie sprawnościowe w zespołowych grach sportowych, Wydawnictwo AWF, Katowice.

Bondarowicz M., Grochowski J., 1976, Rugby, Wydawnictwo AWF, Warszawa. 
Deutsch M., Lloyd R., 2008, Effect of order of exercise on performance during a complex training session in rugby players, „Journal of Sports Sciences”, vol. 26(8), s. 803-809.

Duthie G., 2006, A Framework for the Physical Development of Elite Rugby Union Players. „International Journal of Sports Physiology and Performance", vol. 1, s. 2-13.

Duthie G., Pyne D., Hopkins W., Livingstone S., Hooper S., 2006, Anthropometry profiles of elite rugby players: quantifying changes in lean mass, „British Journal of Sports Medicine”, vol. 40, s. 202-207.

Gamble P., 2004, Physical preparation for Elite-Level Rugby Union Football, „Strenght and Conditioning Journal", vol. 26(4).

Harris H., 1972, Sport in Greece and Rome, Thames \& Hudson, New York.

Naglak Z., 1994, Zespołowa gra sportowa, Wydawnictwo AWF we Wrocławiu, Wrocław.

Lipoński W., 2001, Encykopedia sportów świata, Oficyna Wydawnicza Atena, Poznań.

Pennington J., Laubach L., De Marco G., Linderman J., 2010, Determining the Optimal Load for Maximal Power Output for the Power Clean and Snatch in Collegiate Male Football Players, „Journal of Exercise Physiology", vol. 13, no 2.

Płatonow W.N., Sozański H., 1991, Optymalizacja struktury treningu sportowego, RCMSKFiS, Warszawa.

Poprawski B., Winkler A., 1976, Metoda określania optymalnego ciężaru sztangi w wybranych ćwiczeniach treningowych, Wydawnictwo AWF w Poznaniu, Poznań.

Powała-Niedźwiecki M., 2005, Poradnik dla instruktorów i trenerów rugby, PWZN, PZR, Warszawa.

Rakowski M., 2006, Obciążenia treningowe a wynik sportowy - między teorią a praktyką, „Sport Wyczynowy", $\mathrm{nr}$ 3-4.

Schwartz L.H., 2005, Reflections on Strength, Gender and Lifting Formulas. „Iron Game History”, vol. 8, Issue 4, s. 30-32.

Sozański H., 2005, Systemowe uwarunkowania modelu treningu młodocianych $i$ ich wpływ na rozwój karier, (w:) D. Śledziewski, A. Kuder, K. Perkowski (red.), Modelowe rozwiązania treningu w szkoleniu młodzieży uzdolnionej sportowo, PTNKF, Warszawa, s. 9-27.

Sozański H., Adamczyk J., Siewierski M., 2010, Etapizacja procesu szkolenia sportowego, teoria i rzeczywistość, Wydawnictwo AWF w Poznaniu, Poznań.

Trzaskoma Z., Trzaskoma Ł., 2001, Kompleksowe zwiększanie siły mięśniowej sportowców, Centralny Ośrodek Sportu, Warszawa.

Vanderburgh, P.M. Batterham, A.M., 1999, Validation of the Wilks powerlifting formula. / Validation de la formule de Wilks pour comparer les performances des halterophiles en fonction de leur poids corporel. „Medicine \& Science in Sports \& Exercise”, vol. 31, Issue 12, s. 1869-1875.

Wachowski E., Strzelczyk R., 1991, Atuty cech motrycznych, „Trening”, nr 1(9), s. 106-114.

Wachowski E., Strzelczyk R., 1999, Trafność pomiaru motorycznych cech kondycyjnych, Wydawnictwo AWF w Poznaniu, Poznań.

Wachowski E., Strzelczyk R., Osiński W., 1987, Pomiar sprawności motorycznej osobników uprawiających sport, wyniki badań, Wydawnictwo AWF w Poznaniu, Poznań.

Wachowski E., 1977, Wpływ pracy i mocy użytkowej na wybrane cechy motoryczne i morfologiczne, Wydawnictwo AWF w Poznaniu, Poznań.

Ważny Z., 1986, Modelowe wskaźniki cech mistrzostwa sportowego, RCMSKFiS, Warszawa.

Zaciorski W., 1970, Kształcenie cech motorycznych sportowca, Sport i Turystyka, Warszawa.

Zatsiorsky V.M., 1995, Science and Practice of Strength Training, Human Kinetics, Champaign. 